\title{
Water quality assessment of the Elemi River, Ado-Ekiti, Ekiti State, Nigeria
}

\author{
*Richard Akinyeye, Ibiyinka Ogunlade \\ Department of Chemistry, Ekiti State University, P. M. B. 5363, Ado-Ekiti, Ekiti State, Nigeria \\ E-mail: richard.akinyeye@eksu.edu.ng
}

\begin{abstract}
Physicochemical parameters of water along the Elemi River located within the Iworoko-AdoEkiti axis of Ekiti State was assessed as a pre-implementation process of small hydroelectric power (SHP) plant installation of Ekiti State University, Nigeria which is believed, will solve the problem of incessant interrupted supply of electricity when completed.The results of water quality test from three sites (upstream, downstream and midstream) showed that there was no significant difference in the physical parameters (temperature, turbidity and conductivity) found to be within the limit of WHO standard. Chemical tests showed pH, total dissolved solids (TDS), total solids (TS), total suspended solids (TSD), total alkalinity, acidity (as $\mathrm{CaCO}_{3}$ ), total hardness, chloride, nitrate, sulphate, dissolved oxygen (DO), biological oxygen demand (BOD) were of varying values within tolerable limits.Mineral profiles using Atomic Absorption Spectroscopy (AAS) revealed presence of minerals such as $\mathrm{Na}, \mathrm{K}, \mathrm{Ca}, \mathrm{Mg}$ and $\mathrm{Zn}$. Fe level was very low ranging from 0.07-0.14ppm. Heavy metals such as $\mathrm{Cu}, \mathrm{Cd}, \mathrm{Cr}, \mathrm{Pb}$ were not detected in the samples, indicating that toxic metals would not constitute any health hazard. All the microbiological analysis attests to low bacterial counts and absence of pathogens. These results suggest that the characteristics of waters along the Elemi River would be suitable for both domestic and commercial purposes as at present.
\end{abstract}

Keywords:Elemi River, Water quality, Community, Small Hydroelectric Power (SHP)

\section{Introduction}

Water is a natural resource for all living creatures on earth that determines many human activities, population growth, development, urbanisation and industrialisation. There is virtually any human activity that is not influenced by water. It is used for drinking, cooking, washing, irrigation, farming, industrial operations, etc. In fact without it life will be non-existent. Water is life $[1,2]$. Water is the elixir of life and its importance has been traced back to the beginning of the earth, as earth is the only known planet in the solar system processing water and oxygen, the basic raw material to support life [3]. The availability of good quality water for man is therefore an essential pre-requisite for good quality of life and sustainable development.

Water accounts for about three quarters of the earth surface. Most of the water is however not readily accessible as it exists in oceans, ice caps, underground aquifers and as water vapour. Only a small proportion is directly available to man on the earth surface as rivers, streams, rain and springs. While underground water could only be reached through wells and boreholes, some water comes from springs that ooze out water from surface soil where water aquifers are close to the top soil of the earth surface. The rain water helps to sustain plant life and for equilibration of the ecosystem. The excess water from rainfall runs steadily into rivers, lakes and the sea along a network of rivers [4].

Surface water and ground water sources serve as major routes for the supply of raw water for processing into potable and general domestic purposes. While the surface water comes from rivers, streams and lakes, the ground water comes from wells and boreholes. Many communities depends on these sources to access drinking water and particularly in Ekiti State where most portable water supply provided by the Government are not readily within reach by many people. It is therefore important that the available natural waters are accumulated by building embankments round the rivers to form dams, which could be distributed for irrigation or hydroelectric power generation projects and could also be processed into acceptable water quality and distributed for domestic consumption.

Although, there are many rivers and streams in Ekiti State, many of them fall below the level which makes them not suitable for dam construction especially during the dry season. A dam demands constant water supply for both dry season and rainy season. The point where the dam will be sited along a river course must therefore guarantees adequate volume of impounded water to service the population in the targeted community. Presently, Ekiti State has some water dams where reasonable quantities of water is impounded, treated and distributed to the localities. These include the Little Ose dam at Egbe Ekiti, Ero dam, Itapaji dam and Ado Ekiti waterworks. The present population and developmental activities in the state demands new dam additions to serve the populace. Hence the step taken by Ekiti State University towards construction of a small dam on Elemi River that flows along the campus is justified. 
Elemi River in Ekiti State serves as a good source of surface water that could be harvested for the construction of a water dam to serve the teaming population of Iworoko and part of Ado Ekiti where the Ekiti State University is located. Elemi River originates from natural spring water in Igede Ekiti which flows through the forest into the University land and later runs across Ado - Iworoko road to Afao Ekiti as shown in Figure 1. The present high developmental rate in the city of Ado Ekiti calls for additional source of supply of regular potable water to the community. It is also a channel good for hydro-electric power generation that would solve the incessant interrupted supply of electricity for the University community and it's environ.

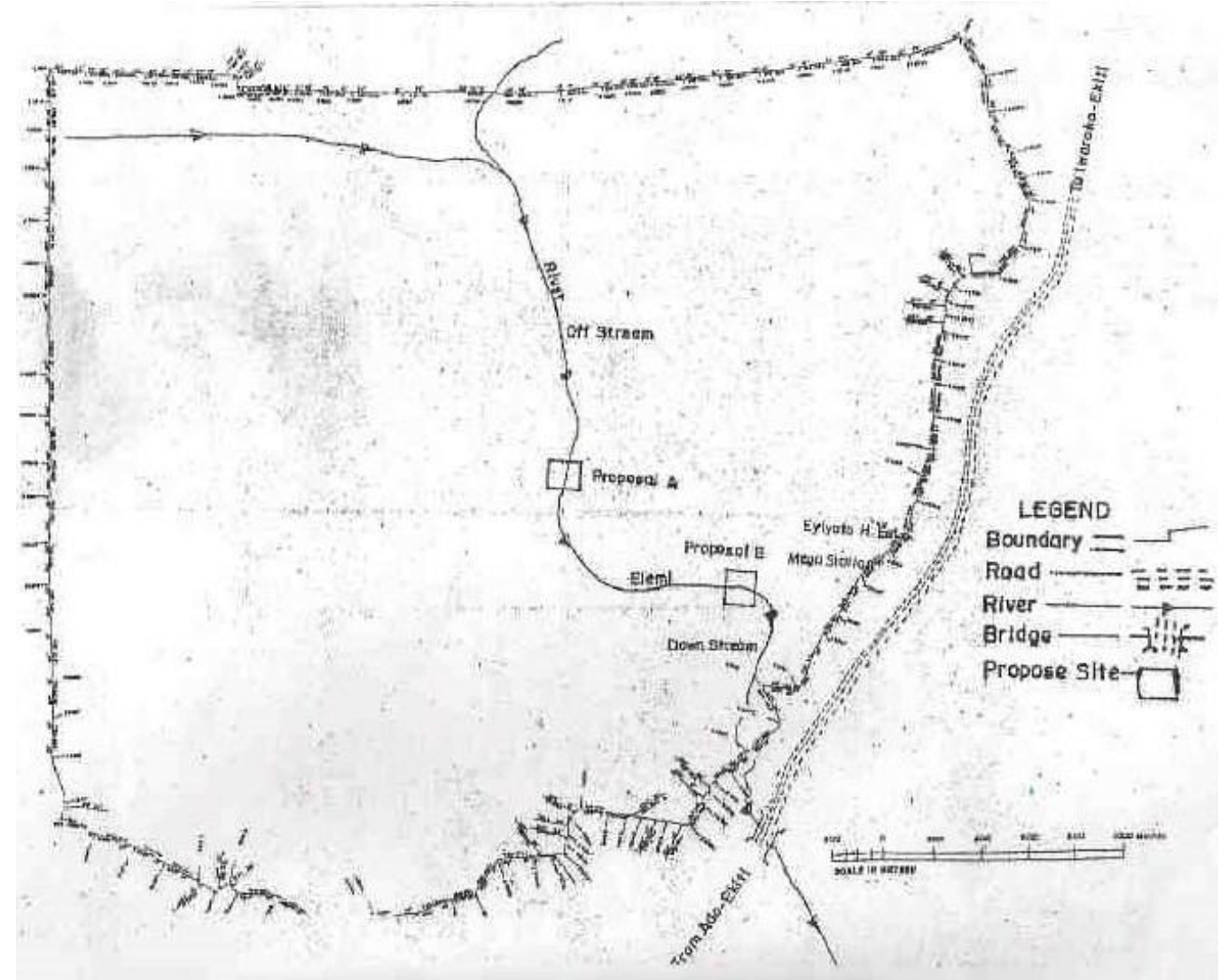

Figure 1: A sketch of Ekiti State University land indicating the proposed site for the hydro-electric power installation along Elemi River.

Water quality relates to the physical, chemical and biological characteristics of water. It is used to access drinking water safety for humans and also for the health of the ecosystem. The water quality audit help to identify source(s) of pollution so as to further probe the environment for the sources and to initiate possible control actions.

It is therefore important to elucidate the current water quality characteristics of Elemi River,which will serve for proper monitoring, process control and auditing of the physicochemical, minerals and microbiological qualities of the river water. In doing this, three locations namely, upstream (US), midstream (MS) and downstream (DS) have been selected along the river course for quality examination. The data obtainable will serve for the purpose of pre and post implementation and management action in the hydroelectric power project and for good and sustainable quality of life for the larger population of end users.

The aims of this work therefore are to document the hydrological parameters of water from Elemi River for the purposesof ascertaining the water quality, treatment that are to be carried out to make it fit for domestic applications and capture the present hydrological data for modelling the anticipated effects that could arise after embankment of the river course.

\subsection{Study Area}

\section{Materials And Methods}

The study was carried out in July, 2015 on samples drawn from the Odo Ayo end of Elemi River, located along the Ekiti State University land, Nigeria. It lies between latitude $7^{\circ} 45^{\prime} \mathrm{N}$ and $5^{\circ} 20^{\prime} \mathrm{E}$ of the equator. Ado - Ekiti is the capital city of Ekiti State in the South-western Nigeria.The Figure 2 below shows the study 
area and differentfrom where samples were taken and described as upstream(UM), midstream (MS) and downstream (DS).
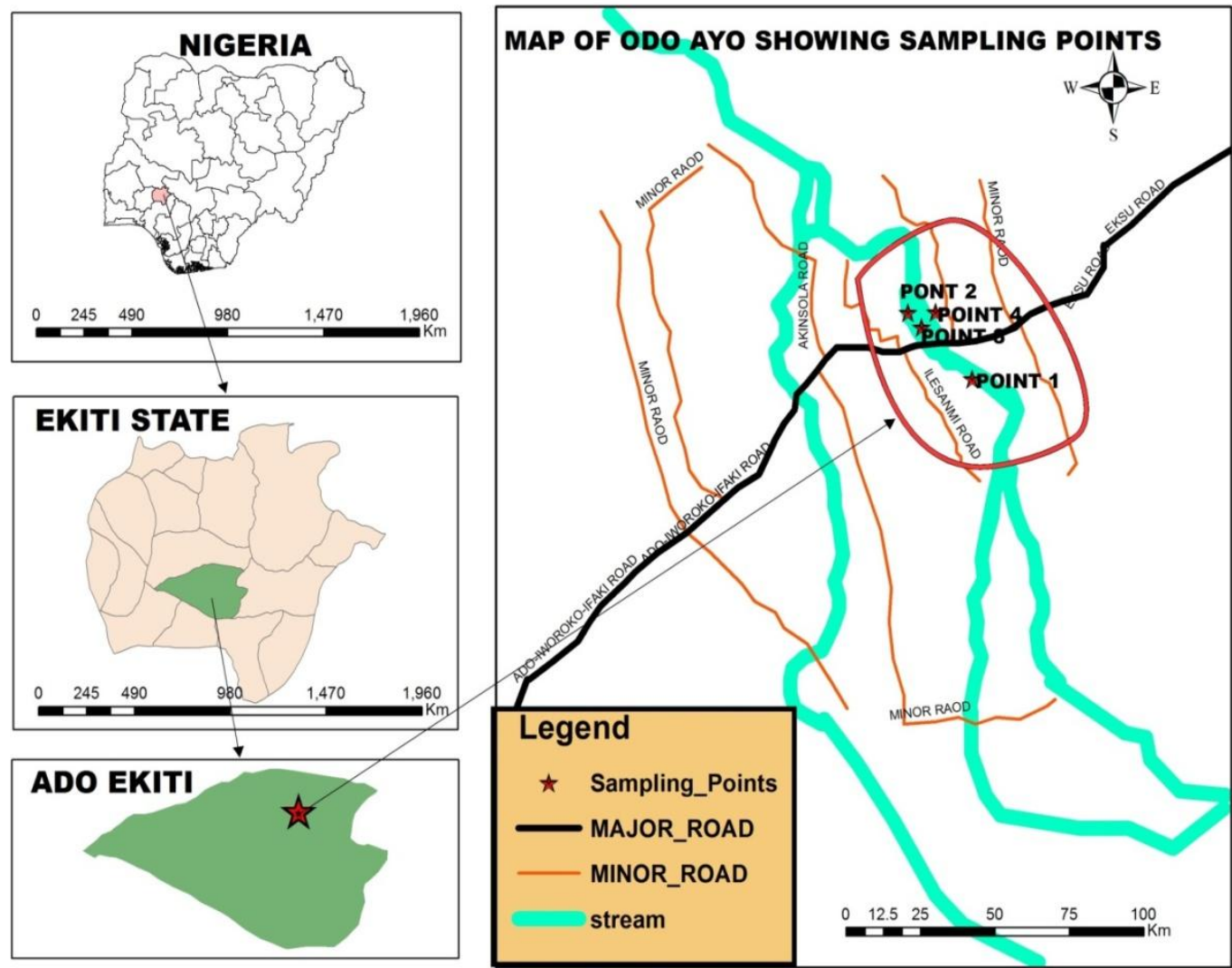

Figure 2: (1) Map of Nigeria showing Ekiti State, (2) Map of Ekiti State showing Ado Ekiti LGA, (3) Map of Ado Ekiti LGA showing the study area and, (4) Map of the study area of Elemi River (a.k.a. Odo Ayoalong Iworoko Road, Ado Ekiti) showing possible sampling points from where the US, MS and DS samples were taken.

\subsection{Sample collection}

Water samples from the Elemi River were obtained at upstream, midstream and downstream locations within the Ekiti State University land in July 2015. The samples were collected with clean, sterile two litres wide mouthed plastic bottles which were rinsed with the sample before being filled. The temperature of the samples was measured alongside $\mathrm{pH}$ at each sampling point by the use of a calibrated portable HANNA $\mathrm{pH}$ meter. The electrical conductivity (EC) and total dissolved solids were also measured in situ by using a calibrated HANNA TDS meter.

\subsection{Sample preservation}

In order to minimise drastic changes in the physicochemical and microbiological characteristics of the water samples between the time of sample collection and analyses, the water samples were preserved by cooling to $4^{\circ} \mathrm{C}$ using ice packs (the ice packs were taken along to the sampling points). $1 \mathrm{ml}$ of nitric acid was added into each sample bottle for heavy metals analyses before their final preservation in the refrigerator in the laboratory.

\subsection{Physico-chemical analysis}

The physico-chemical tests included the determination of colour, odour, temperature, turbidity, total solids, conductivity, $\mathrm{pH}$, total dissolved solids (TDS), total solids (TS), total suspended solid (TSS), total alkalinity, acidity as $\mathrm{CaCO}_{3}$, total hardness,chloride, nitrate, sulphate, phosphate, dissolved oxygen (DO) and biological oxygen demand (BOD). The methods of FAO [5] and APHA[6] were used for the determinations.

\subsection{Minerals analysis}

The minerals analysed for in the samples includes $\mathrm{Na}, \mathrm{K}, \mathrm{Ca}, \mathrm{Mg}, \mathrm{Zn}, \mathrm{Fe}, \mathrm{Cu}, \mathrm{Pb}, \mathrm{Cd}$ and $\mathrm{Cr}$. Sodium and potassium were determined with the help of flame photometer. The instrument is standardised with known 
concentrations of sodium ion (1 to $100 \mathrm{mg} / \mathrm{L}$ ) and potassium ions ( 1 to $5 \mathrm{mg} / \mathrm{L}$ ) respectively to get a calibration plot. The samples having higher concentrations are suitably diluted with distilled water and the dilution factor is applied to the observed values. The concentrations of the heavy metals: $\mathrm{Cd}, \mathrm{Zn}, \mathrm{Cr}, \mathrm{Cu}, \mathrm{Pb}$ and $\mathrm{Fe}$ were detected using atomic absorption spectrometer equipment. Standards were prepared for each metal using the salts of the metals. The instrument was switched on and the relevant hollow cathode lamps for each metal. Air acetylene flame was used. Standards for each metal were thereafter sprayed into the flame as well as the sample with their corresponding absorbance taken. Values from both the standards and samples were read under the same condition.

\subsection{Microbiological analysis.}

The determination of the total heterotrophic bacterial counts was done using the pour plate technique of Harrigan and McCane[7] andCollins and Lyne[8] was adopted using standard plate count agar (Oxoid, England). The total coliform and Escherichia coli (fecal coliform) counts were enumerated on McConkey agar, as described by Oxoid[9] and Itah [10].

\subsection{Results}

\section{Results And Discussion}

The hydrological characteristics investigated in this work includes transparency, temperature, $\mathrm{pH}$, conductivity, total dissolved solids, inorganic ions, heavy metals, microbial load amongst other parameters. The samples were taken at the indicated marked points in Figure 1 that represented the upstream, midstream and downstream along the Elemi River course. The mean of duplicate analysis carried out on the Elemi River at the Upstream (US), Midstream (MS) and Downstream (DS) are presented in Table 1. The means and standard deviations amongst values obtained from the three points are equally presented to see the extent of similarities and variations at the different sampling points. The variations in some of the parameters are further presented on clustered pyramidal graphs to pictorially show variations in parameters amongst categories from the different sampling points UP, US and DS respectively. Figures 3, 4, 5, 6, 7, 8 and 9 present the variations for $\mathrm{pH}$, TDS, TS, total alkalinity, acidity as $\mathrm{CaCO}_{3}$, dissolved oxygen and biological oxygen demand respectively. Figure 10 present a bar chart of variations in concentrations of different minerals ( $\mathrm{mg} / \mathrm{L}$ ) amongst US, MS and DS water samples

Table 1: Physicochemical, minerals and microbial parameters in Elemi River water samples at upstream, midstream and downstream locations within the Ekiti State University land.

\begin{tabular}{|c|c|c|c|c|c|}
\hline PARAMETERS & UP-STREAM & MID-STREAM & DOWN-STREAM & MEAN & STD DEV $( \pm)$ \\
\hline \multicolumn{6}{|l|}{ PHYSICAL } \\
\hline Colour & $\begin{array}{ll}\begin{array}{l}\text { Slightly } \\
\text { coloured }\end{array} & \text { yellow } \\
\end{array}$ & $\begin{array}{l}\begin{array}{l}\text { Slightly } \\
\text { coloured }\end{array} \\
\end{array}$ & $\begin{array}{ll}\begin{array}{l}\text { Slightly } \\
\text { coloured }\end{array} & \text { yellow } \\
\end{array}$ & NA & NA \\
\hline Temperature $\left({ }^{\circ} \mathrm{C}\right)$ & 25.5 & 25.0 & 25.0 & 25.2 & 0.3 \\
\hline Turbidity (NTU) & 0.03 & 0.02 & 0.04 & 0.03 & 0.01 \\
\hline Conductivity $(\mu \mathrm{s} / \mathrm{cm})$ & $1.96 \times 10^{2}$ & $1.97 \times 10^{2}$ & $2.01 \times 10^{2}$ & 198 & 2.65 \\
\hline $\mathrm{pH}$ & 7.70 & 8.00 & 7.80 & 7.83 & 0.15 \\
\hline TDS (mg/L) & 140.25 & 144.15 & 156.15 & 146.85 & 8.30 \\
\hline Total Solids (mg/L) & 155.30 & 158.95 & 171.45 & 161.90 & 8.47 \\
\hline Total suspended solid (mg/L) & 15.00 & 14.80 & 15.30 & 15.03 & 0.25 \\
\hline Total alkalinity (mg/L) & 105.00 & 120.00 & 140.15 & 121.72 & 17.64 \\
\hline Acidity as $\mathrm{CaCO}_{3}(\mathrm{mg} / \mathrm{l})$ & 100.00 & 220.05 & 220.20 & 180.06 & 69.35 \\
\hline Sulphate (mg/l) & 11.28 & 12.50 & 8.73 & 10.84 & 1.92 \\
\hline Phosphate (mg/L) & 3.50 & 5.00 & 3.15 & 3.88 & 0.98 \\
\hline $\mathrm{DO}(\mathrm{mg} / \mathrm{L})$ & 8.50 & 7.75 & 7.50 & 7.92 & 0.52 \\
\hline BOD $(\mathrm{mg} / \mathrm{L})$ & 3.40 & 3.50 & 3.35 & 3.42 & 0.08 \\
\hline \multicolumn{6}{|l|}{ MINERALS } \\
\hline $\mathrm{Na}$ & 16.50 & 19.35 & 20.3 & 18.72 & 1.98 \\
\hline $\mathrm{K}$ & 15.85 & 18.35 & 19.20 & 17.97 & 1.84 \\
\hline $\mathrm{Ca}$ & 40.00 & 47.00 & 51.55 & 46.18 & 5.82 \\
\hline $\mathrm{Mg}$ & 52.00 & 85.00 & 34.00 & 57.00 & 25.87 \\
\hline $\mathrm{Zn}$ & 2.35 & 2.55 & 3.50 & 2.80 & 0.61 \\
\hline $\mathrm{Fe}$ & 0.10 & 0.40 & 0.14 & 0.21 & 0.16 \\
\hline
\end{tabular}


Water quality assessment of the Elemi River, Ado-Ekiti, Ekiti State, Nigeria

\begin{tabular}{|l|l|l|l|l|l|}
\hline Cr & ND & ND & ND & ND & ND \\
\hline MICROBIAL & $0.30 \times 10^{2}$ & $0.45 \times 10^{2}$ & $0.55 \times 10^{2}$ & & \\
\hline Total plate count $(\mathrm{cfu} / \mathrm{mL})$ & ND & ND & ND & ND & ND \\
\hline Pathogens $(\mathrm{cfu} / \mathrm{mL})$ & \multicolumn{4}{|l|}{} & \\
\hline
\end{tabular}

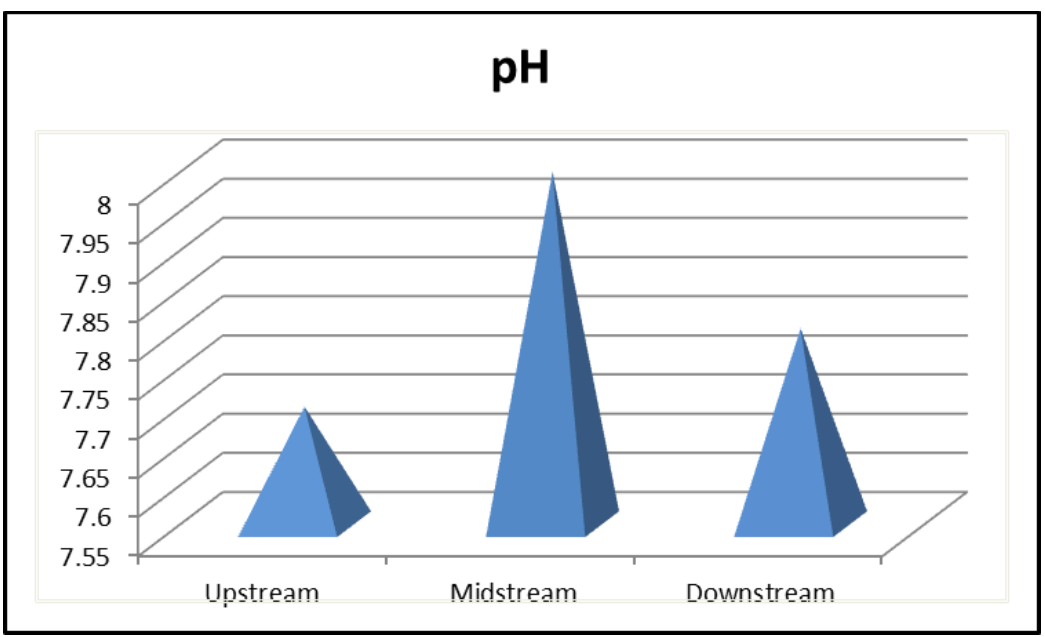

Figure 3: Variations in $\mathrm{pH}$ amongst US, MS and DS water samples

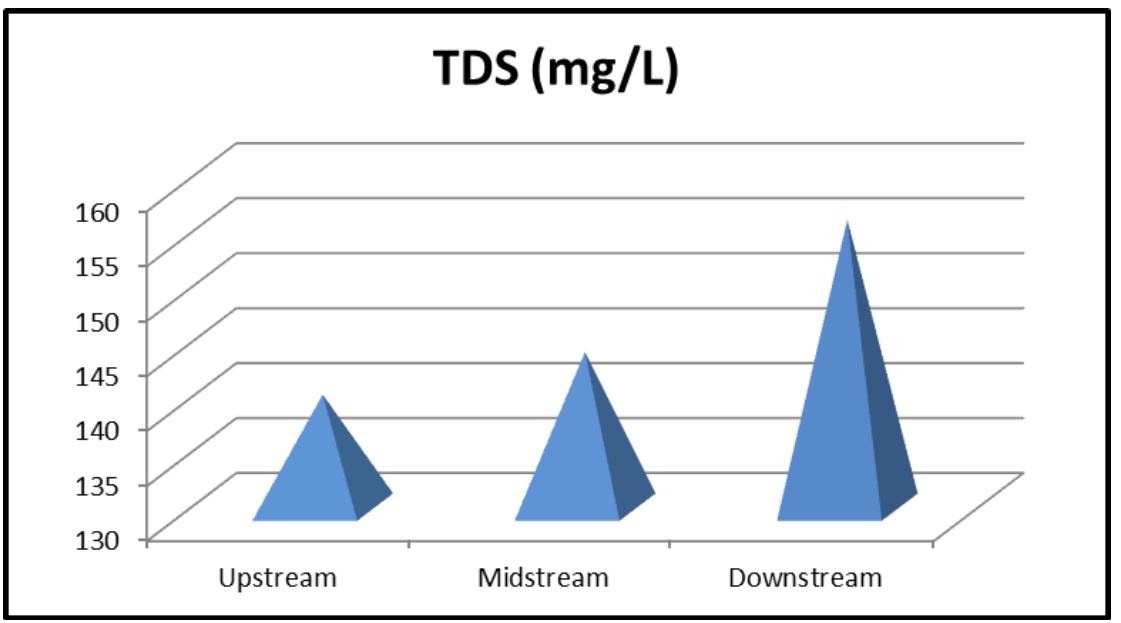

Figure 4: Variations in total dissolved solids (mg/L) amongst US, MS and DS water samples

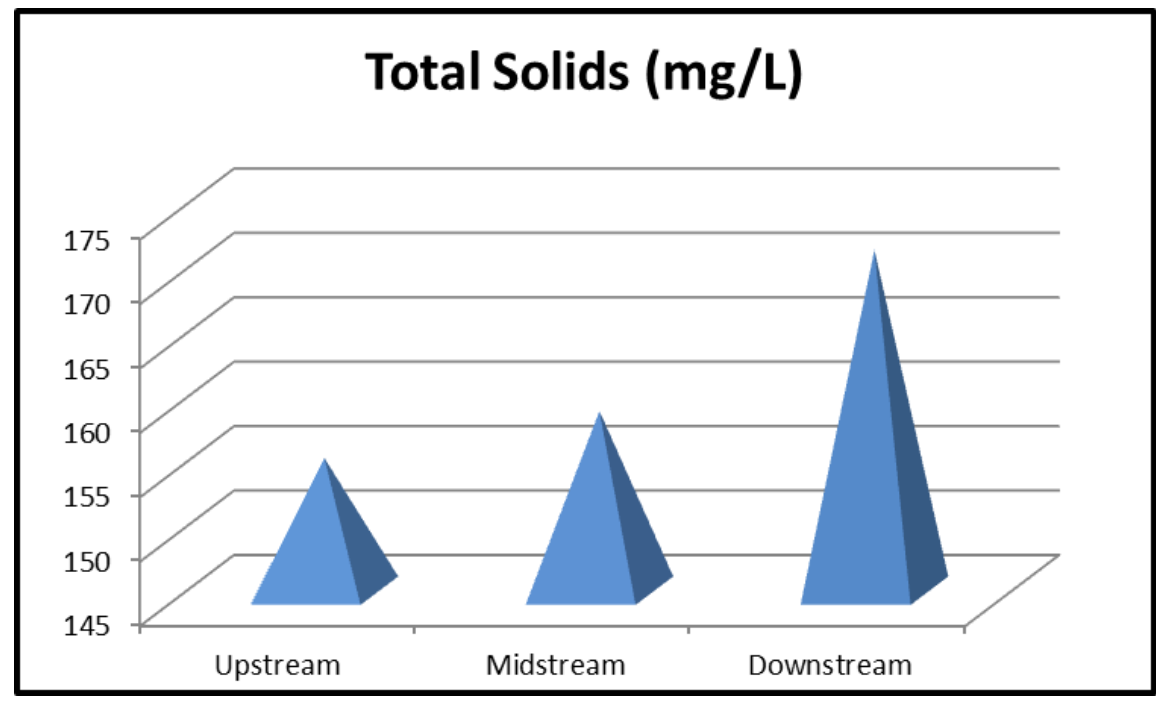

Figure 5: Variations in total solids (mg/L) amongst US, MS and DS water samples 


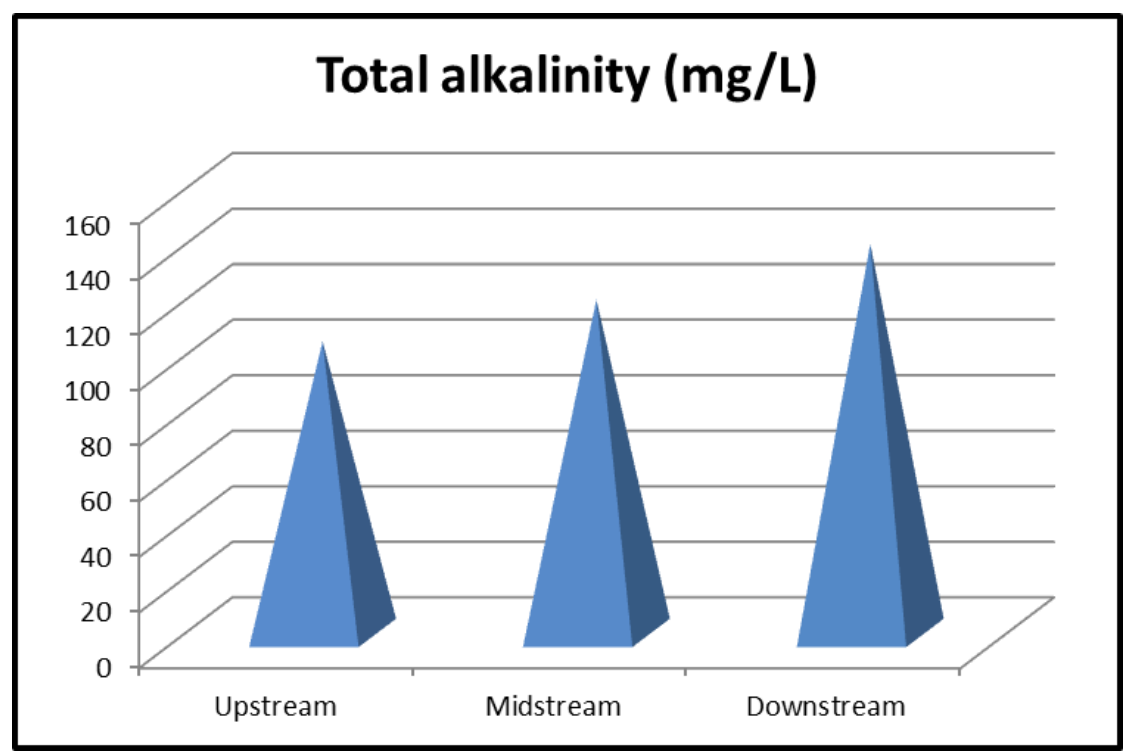

Figure 6: Variations in total alkalinity (mg/L) amongst US, MS and DS water samples

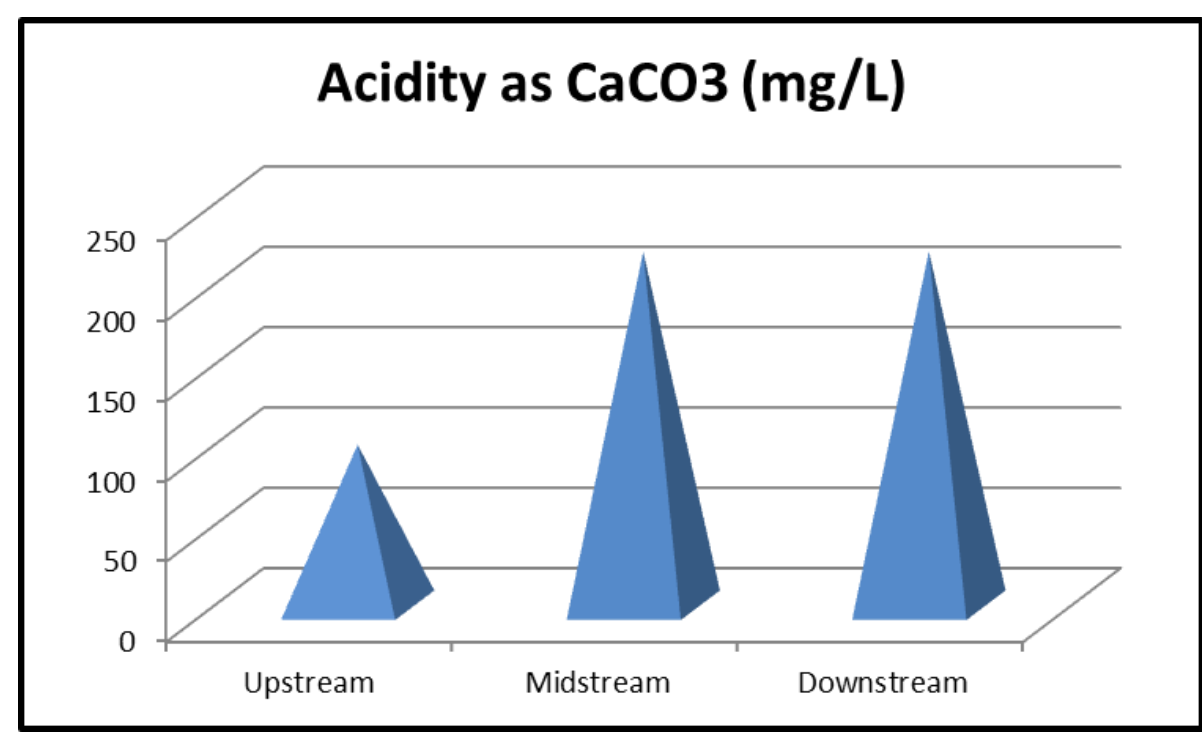

Figure 7: Variations in acidity as $\mathrm{CaCO}_{3}(\mathrm{mg} / \mathrm{L})$ amongst US, MS and DS water samples

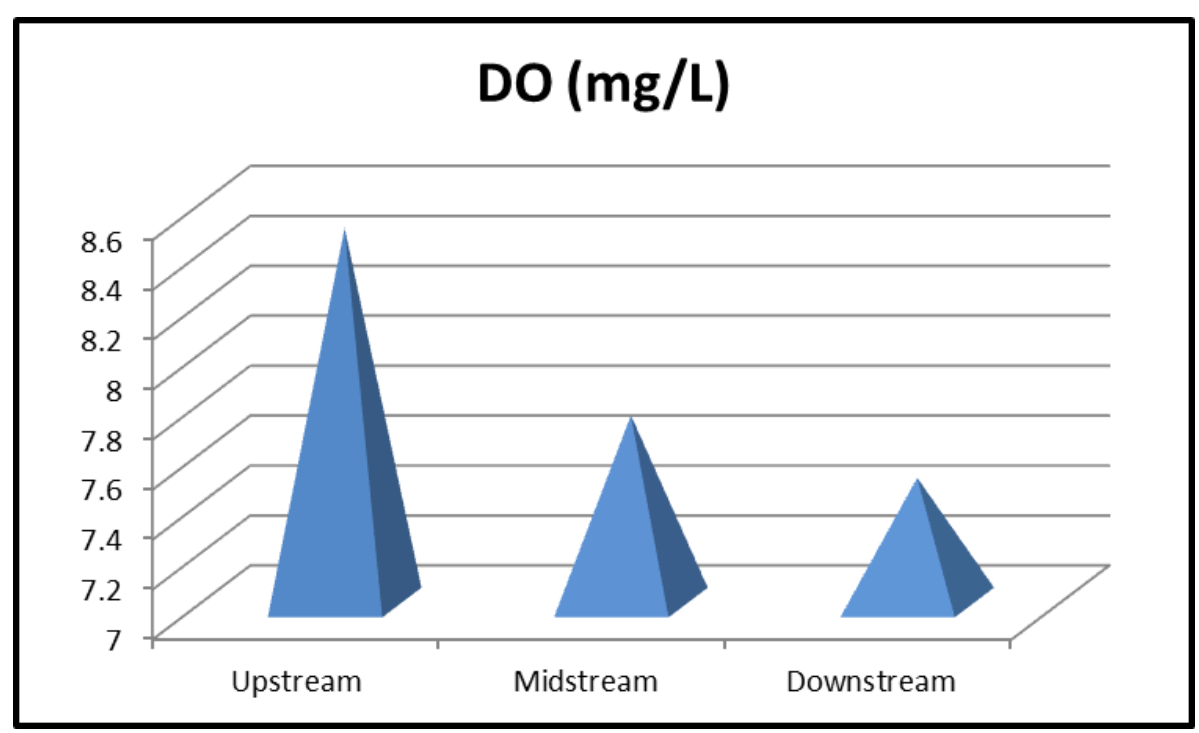

Figure 8: Variations in concentrations of dissolved oxygen (mg/L) amongst US, MS and DS water samples. 


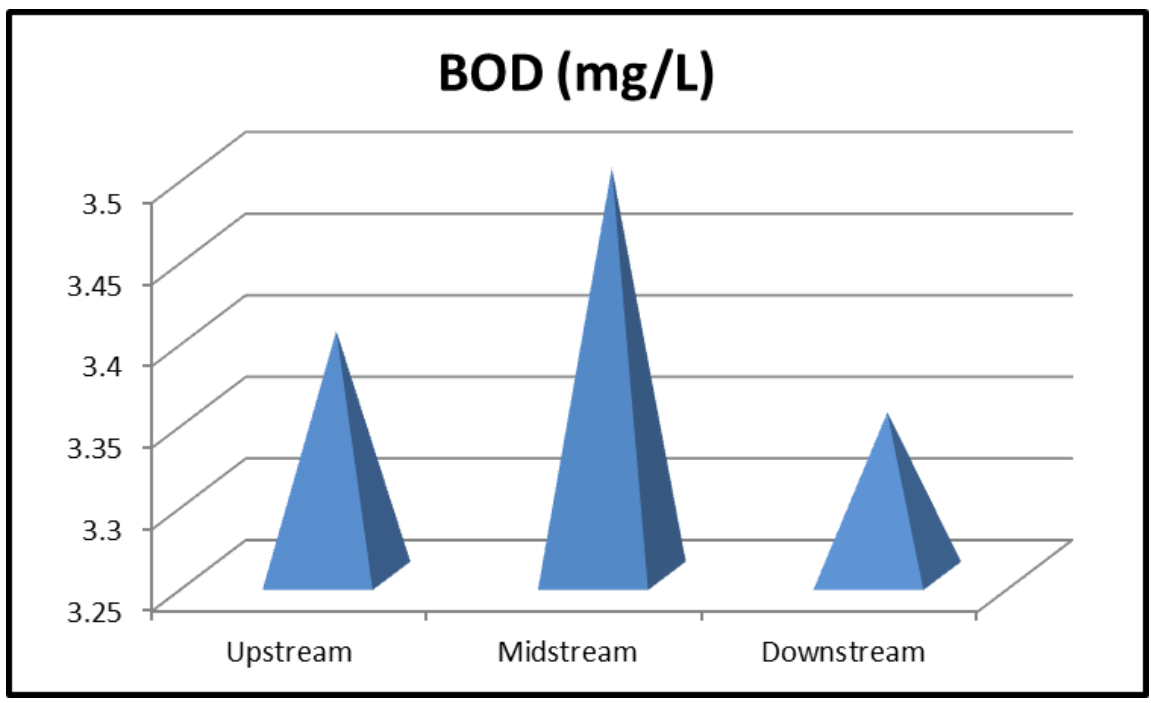

Figure 9: Variations in concentrations of biological oxygen demand (mg/L) amongst US, MS and DS water samples

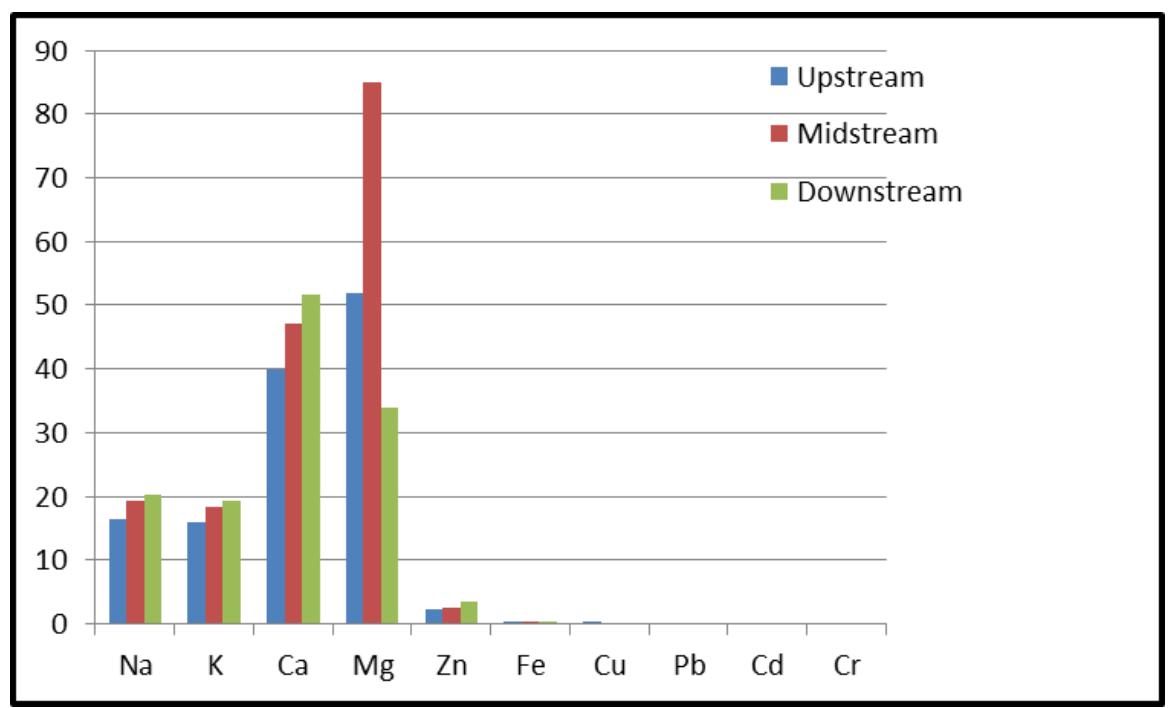

Figure 10: Variations in concentrations of different minerals (mg/L) amongst US, MS and DS water samples

\section{Discussion}

The temperature in the samples ranged from 25.0 to $25.5^{\circ} \mathrm{C}$ which is about $1^{\circ} \mathrm{C}$ less than ambient temperature of $26^{\circ} \mathrm{C}$ at the time of sampling. The slight variation in the temperatures might be due to difference in the vegetation surrounding each site.Rosegrantet al.[11] and Awake [12] have shown that theslight difference in temperature of water sample and the environment do result from nature of sampling sites, differences in surface area, vegetation, pollutant land, weather and season. Results obtained were synonymous to those obtained by Gras and Leverque-Duwat[13] when they worked on the physicochemical parameters of the coastal Lake Chad and recorded a surface water temperature between 20 to $30.4^{\circ} \mathrm{Cat}$ different times and seasons. Temperature is an important factor that influences primary production in water reservoirs [14].

The water samples at the US, MS and DS showed that the river was slightly yellow coloured. This is an indication that the Elemi River may not be portable and wholesome and may carry some extraneous pollutants.The slight yellow colouration might be due to the clay soil through which the river had flown through. The observed odour was not objectionable in the water samples collected at US, MS and DS sampling points. This is an indication that serious biochemical reactions leading to foul odour generation may be minimal.

Turbidity values (NTU) for the water samples were quite close. It ranged between 0.02 (MS) to 0.04 (DS) with mean value of 0.03NTU. The observed values were within the maximum allowable limits of 5NTU by WHO [15]. Since turbidity measures the water cloudiness [16], therefore, the Elemi River is not too turbid for aquatic lives, fishery and other agricultural purposes. The low level of turbidity observed in the study may be due to absence of disease-causing microorganisms in the river. 
Electrical conductivity (EC) measures the amount of dissolved ions in water. It is the conductance of 1 $\mathrm{cm}$ of solution. In this research work, conductivity measured as $\mu \mathrm{s} / \mathrm{cm}$ ranged from $1.96 \times 10^{2}$ to $2.01 \times 10^{2}$. The US sample had the lowest conductivity value of $1.96 \times 10^{2}$ followed by the MS $1.97 \times 10^{2}$ and DS $2.01 \times 10^{2}$ respectively. This trend in the conductivity values showed little differences which is indicative that no serious pollutants is being introduces as effluents into the river between the sampling points.

The $\mathrm{pH}$ of the Elemi River water samples ranged from 7.70 (US) to 8.00 (MS)samples respectively. The $\mathrm{pH}$ values obtained in this work were within the WHO [15] and EPA standard [17] of 6.5-8.5. The pH value of river water is most important in determining the corrosive nature of water. The lower the $\mathrm{pH}$ value, the higher is the corrosive nature of water. The observed slight differences in the $\mathrm{pH}$ values obtained for the three samples may be due to reduced rate of photosynthetic activity and the assimilation of carbon dioxide and bicarbonates at the different sites. The higher $\mathrm{pH}$ value of 8.00 observed in the MS sample suggests that carbon dioxide, carbonate-bicarbonate equilibrium is affected more due to changes in the physicochemical condition [18]. If more $\mathrm{CO}_{2}$ is being introduced to the water, then more $\mathrm{HCO}_{3}^{-}$will be formed and thus acidity will slightly increase (lower $\mathrm{pH}$ value). The equation below shows the effect of change in the physicochemical condition on the carbon dioxide, carbonate and bicarbonate equilibrium which could adduce for the trend presented in Fig. 3. $\mathrm{Ca}^{2+}+2 \mathrm{HCO}_{3}^{-}=\mathrm{CaCO}_{3}+\mathrm{CO}_{2}+\mathrm{H}_{2} \mathrm{O}$

The result for total dissolved solids (TDS) ranged from $140.25 \mathrm{mg} / \mathrm{L}$ (US)to $156.15 \mathrm{mg} / \mathrm{L}$ (DS) with MS value of $144.15 \mathrm{mg} / \mathrm{L}$ and mean value of $146.85 \mathrm{mg} / \mathrm{L}$. Results obtained in this research showed that Elemi River had some dissolved particles and minerals especially at the DS. Figures 4 and 5 shows that the trend of variation in TDS is similar to that for TS in the samples.. The total suspended solid in the Elemi River sample is $9.3 \%$ of the TS while the TDS was $90.7 \%$.The results obtained for total solids, total suspended solids and total dissolved solids were all within the allowable limits/standard of $500 \mathrm{mg} / \mathrm{L}$ by WHO[15].

Total alkalinity ranged from $105.00 \mathrm{mg} / \mathrm{L}$ (US) to $140.15 \mathrm{mg} / \mathrm{L}$ (DS). Similar trend was observed in the acidity $\left(\mathrm{CaCO}_{3}\right)$ trend (Figs 6 and 7). Since $\mathrm{pH}$ and hardness affects the toxicity of many substances in the water, alkalinity therefore acts as a stabiliser for the acidity present in the water.From Table 1, apart from acidity which showed a standard deviation (SD) of \pm 69.35 amongst the US, MS and DS samples, the alkalinity trend had the next highest variation amongst the physical parameters with SD of \pm 17.64 . Total alkalinity is a contribution of hydroxyl, carbonate and bicarbonate and this will also relate to the operational $\mathrm{pH}$ in the river water. At very low $\mathrm{pH}$ of less than 4.5 , there is no alkalinity while at $\mathrm{pH}$ greater than 8.5 ; there is high possibility of free hydroxides in the river, while at intermediate $\mathrm{pH}$ values the alkalinity is mainly from free carbonates. This shows that acidity and alkalinity values of rivers could vary very rapidly thus the need for its continuous monitoring. The equilibrium between carbonate and bicarbonate from time to time determines the observed results at each sampling point [18].

Total hardness (TH) in MS was $82.00 \mathrm{mg} / \mathrm{L}$, US was $91.50 \mathrm{mg} / \mathrm{L}$ and DS was $86.00 \mathrm{mg} / \mathrm{L}$. Hardness of water is caused by the presence of dissolved $\mathrm{Ca}^{2+}$ and $\mathrm{Mg}^{2+}$ ions. The total hardness observed in all the samples with a mean of $86.50 \pm 4.77 \mathrm{mg} / \mathrm{L}$ was within the maximum permissible limit of $500 \mathrm{mg} / \mathrm{L}$ for potable water [15]. The river water could not be classified as soft water category $(<75 \mathrm{mg} / \mathrm{L} \mathrm{TH})$ but fits well into the moderate water category $(75-150 \mathrm{mg} / \mathrm{L} \mathrm{TH})$. At TH values of $>150 \mathrm{mg} / \mathrm{L}$, the water will be deemed as hard water [19]. Results showed that the Elemi River can be a good source of water for washing, since the results showed that the Elemi River is not hard, in other words, it can form lather readily with soap.

The chloride concentrations of $48.18 \pm 7.52 \mathrm{mg} / \mathrm{L}$ for the Elemi River water was less than the maximum limit of $250 \mathrm{mg} / \mathrm{L}$ set by $\mathrm{WHO}[20]$. Nitrate $\left(\mathrm{NO}_{3}^{-}\right)$in water may be due to run off from farmlands where fertiliseris being used, leakage from septic tanks, sewage and erosion of natural deposits. The values of nitrate obtained in this research were $0.13 \mathrm{mg} / \mathrm{L}$ (MS), $0.20 \mathrm{mg} / \mathrm{L}$ (US) and $0.24 \mathrm{mg} / \mathrm{L}$ (DS). All the results obtained for nitrate are within the maximum allowable limits of $50 \mathrm{mg} / \mathrm{L}$ [21]. This is an indication that there is minimal nitrate and chloride pollution of the Elemi River water.

Sulphate and phosphate concentrations of $10.84 \pm 1.92 \mathrm{mg} / \mathrm{L}$ and $3.88 \pm 0.58 \mathrm{mg} / \mathrm{L}$ respectively in the water samples were all below the maximum allowable limit of $500 \mathrm{mg} / \mathrm{L}$ and $10 \mathrm{mg} / \mathrm{L}$ by WHO[20]. Excessive phosphate could originate from run off from farmlands treated with phosphaticfertilizer which can stimulate microbial growth, odour and rancidity which could invariably lead to eutrophication of rivers.

Figures 8 and 9 shows the pattern of variations in the values of dissolved oxygen (DO) and biological oxygen demand (BOD) at the different sampling points. The DO concentration gives an indication of the relative availability of dissolved oxygen in the river and its availability to support life through aerobic respiration. The BOD value indicates the extent of organic matter pollution and the concomitant treatment process that will be required to get rid of the pollutants. The graphs reveal slight differences amongst values for different sampling points. The mean value of $7.92 \pm 0.52 \mathrm{mg} / \mathrm{L}$ for the $\mathrm{DO}$ and $3.42 \pm 0.08 \mathrm{mg} / \mathrm{L}$ value for BOD are pointers to very low pollution of the river water and that minimal treatment will be required to get rid of the organic pollutants contained in the water. 
The analytical data for different cations analysed for in the water samples is contained in Table 1 and Figure 10. Sodium and potassium had similar values of $18.72 \pm 1.98$ and $17.97 \pm 1.84 \mathrm{mg} / \mathrm{L}$ which were within the usual values obtainable for surface and ground waters. Iron (Fe) concentrations ranged from $0.10 \mathrm{mg} / \mathrm{L}$ (US) to $0.40 \mathrm{mg} / \mathrm{L}$ (MS) and a mean value of $0.21 \pm 0.16 \mathrm{mg} / \mathrm{L}$. The high Fe concentration at the MS could result from anthropogenic activity of disposal of old vehicles and mechanical wastes around the river stream. Fe in drinking water is good for human health as it is responsible for the formation of the protein haemoglobin which transports oxygen to all the cells in the body. But when $\mathrm{Fe}$ is present in a higher concentration above the maximum allowable limits of $0.3 \mathrm{mg} / \mathrm{L}$ (WHO 2004) [15], it may lead to a metallic taste and odour in drinking water.

$\mathrm{Ca}^{2+}$ concentrations in the US $(40.00 \mathrm{mg} / \mathrm{L}), \mathrm{MS}(47.00 \mathrm{mg} / \mathrm{L})$ and DS $(51.55 \mathrm{mg} / \mathrm{L})$ samples respectively and Mg concentrations in US $(52.00 \mathrm{mg} / \mathrm{L})$, MS $(85.00 \mathrm{mg} / \mathrm{L})$ and DS $(34.00 \mathrm{mg} / \mathrm{L})$ were in tandem with the observed data for the total hardness. The fairly high value obtained for Mg in MS data might have arisen from extraneous factor. Fig. 9 showed that $\mathrm{Mg}$ concentration is the highest cationic mineral in the water samples. WHO [20] recommended a maximum value of $50 \mathrm{mg} / \mathrm{L}$ for $\mathrm{Mg}$ and $200 \mathrm{mg} / \mathrm{L}$ for Ca for potable waters. Excessive magnesium in potable water may give water a bitter taste but it is not usually a health hazard. However, excessive calcium in water could give rise to kidney disorder from the formation kidney and bladder stones [22]. The Elemi River water is therefore not implicated for both $\mathrm{Ca}$ and $\mathrm{Mg}$.

The concentrations of the heavy metals $\mathrm{Cu}, \mathrm{Pb}, \mathrm{Cd}$ and $\mathrm{Cr}$ were all at normal and acceptable limits. $\mathrm{A}$ tolerable and acceptable copper concentration of $0.01 \mathrm{mg} / \mathrm{L}$ was observed at US point while no trace of $\mathrm{Cu}$ was detected in both MS and DS. Similarly $\mathrm{Pb}, \mathrm{Cd}$ and $\mathrm{Cr}$ were not detected in all the samples at the three locations, indicating that toxic metals would not constitute any hazard.

The result of the microbiological analysis in Table 1 reveals low total plate count range of between 20 to 55 colony forming units per $\mathrm{ml}(\mathrm{cfu} / \mathrm{ml})$. This shows very low bacterial contamination in the water. No indication of pathogenic microorganisms was found when assayed for total coliform and Escherichia coli (faecal coliform) counts which showed that the efficiency of Elemi River's self-microbial purification is super. No wonder, the community rightly named the river "Odo Ayo", meaning a river of joy/peace, which implies the availability of quality and sustainable life,could be accessed in the water.

\section{Conclusion}

These results suggest that the characteristics of the water flowing along the Elemi River at the time of this investigation are fairly uniform and steady. The physicochemical, minerals and microbiological parameters are all within regulatory standard specifications for portable water except for the coloration. These suggest that with simple water treatment processes of water accumulation via embankment, physical filtration, coagulation, flocculation, mineralisation, ion exchange, chlorination/ozonisation, the Elemi River water would be suitable for both domestic and commercial purposes. With the usual steady flow of the river, it will indeed be a good location for the establishment of a hydroelectric power project for the University community and parts of Iworoko and the State Capital, Ado Ekiti.

Further seasonal hydro-geological studies on water quality variation and modelling of the Elemi River rheological properties, fluid speed, health implications of eventual embankment of the stream and the current and eventual concentrations of organic matter pollution is on-going.

\section{References}

[1] C. C. Asonye, N. P. Okolie, E. E. Okenwa, and U. G. Iwuanyanwu, Some physico-chemical characteristics and heavy metal profiles of streams and water ways. African Journal of Biotechnology, 2007, 6(5), 617-624

[2] D. S. Rathore, N. Rai, and P. Ashiya, Physicochemical analysis of water of Ayad River at Udaipur, Rafjasthan (India), Int. Jounal of Innovative Research in Science, Engineering and Technology, 2014, 13(4), 11660-11667.

[3] M. Muniyan, and G. Ambedkar, Seasonal variations in physicochemical parameters of water collected from Kedilam River at Visoor Cuddalore District, Tamil Nadu, India. International Journal of Environmental Biology, 2011, 1(2), 15-18.

[4] C. M. A. Ademoroti, Environmental Chemistry and Toxicology, Foludex Press Ltd., Ibadan, 1996, 145-151, 174.

[5] Food and Agricultural Organisation (FAO), Chemical analysis manual for food and water, 5th Edition, FAO Rome, 1997, 1, $20-26$.

[6] APHA, American public health Association, Guideline for portable water. $7^{\text {th }}$ edition, Newyork: WHO press, 1995.

[7] M. G. Harrigan, and M. E. McCane, Laboratory methods in food and dairy microbiology. London: Academic Press, 1976, 33-200.

[8] C. H. Collins, and P. M. Lyne, Microbiological methods. Great Britain: Butterworth, 1976, 151-179.

[9] Oxoid, Oxoid manual of dehydrated culture media, ingredients and other laboratory services, Basingstore, England, 1985

[10] A. Y. Itah, S. M. Etukudo, and E. J. Akpan, Bacteriological and chemical analysis of some rural waters samples in Calabar, Nigeria. West African, Journal of Biology and Applied Chemistry, 1996, 41, 1-10.

[11] M. W. Rosegrant, X. Cai, and S. A. Cline, Water resources and food production: in world water and food to 2025: Dealing with scarcity, 2002, 1-13.

[12] Awake, Are we running out of water. Publication of Jehovah's witnesses. January edition, 2009.

[13] R. I. Gras, and S. leverque-Duwat, Le plankton du lac chari de la portie du Lac Tchad. Cah. O.R.S.T.M. Ser hydrology, 1967, 4, 2597.

[14] W. M. Lewis, Basis for the protection and Management of tropical lakes, Lakes, Reserv. and Res. Manage., 2000, 5, 35-48.

[15] World Health Organisation, Guidelines for drinking water quality, $3^{\text {rd }}$ edition, Switzerland: WHO press pp. 2004, $16,89$.

[16] EPA, US Environmental protection agency, safe drinking water act amendment, 2002. http://www.epa.gov/safe water/mcl.Html. 
[17] EPA, US Environmental Protection Agency safe drinking water act, 2003.

[18] K. R. Karomth, Groundwater assessment development and management, Tata McGraw Hill publishing company Ltd., New Delhi, 1987, 725-726.

[19] O. N. Omaka, I. F. Offor, and I. M. Onwe, Hydro-geometrical attributes and ground water quality of Ngbo Community in Ohaukwu Area Council, Ebonyi State, Nigeria. Rev. Ambient. Agua, 2015, 10, 35-37.

[20] World Health Organisation, Guidelines for drinking water quality criteria. $4^{\text {th }}$ edition, Geneva, 2011, 307-441.

[21] Environmental protection agency (EPA), Effects of metals in drinking water. Environmental quality, 1992, 19(2) 16-18, 20-21.

[22] N. C. Igwemmar, S. A. Kolawole, and L. K. Okunoye, Physical and Chemical Assessment of Some Selected Borehole Water in Gwagwalada, Abuja. International Journal of Scientific and Technology Research, 2013, 2(11), 324-328. 